\title{
Community Perception for the Current Function of Toko Merah in Kota Tua, Jakarta
}

\author{
Yeptadian Sari ${ }^{1}$ \\ ${ }^{1}$ Lecturer of Architecture Department \\ Universitas Muhammadiyah Jakarta \\ Jakarta, Indonesia
}

\author{
Ari Widyati Purwantiasning ${ }^{2}$ \\ ${ }^{2}$ Lecturer of Architecture Department \\ Universitas Muhammadiyah Jakarta \\ Jakarta, Indonesia
}

\begin{abstract}
The suitability between building function and building type is very influential on the sustainability of that building, especially for historical buildings that should be preserved, it is like Toko Merah in Kota Tua, Jakarta. The Toko Merah is a cultural heritage building which means that the building must be protected, preserved and the façade building cannot be changed, which is allowed only to reuse it or so-called Adaptive Reuse. This study finds out about the perceptions of community about Toko Merah which is can be reused to become another function. Nowdays, Toko Merah is a weding hall or rental meeting building. This research is an explorative research with statistical descriptive analysis method. The method of determining the sample by purposive sampling, data collection technique is survey by means of data collection that is questioner. The results of this study said almost all of the respondents stated that the Toko Merah can be reused to become another building function, such as Kota Tua souvenir center.
\end{abstract}

Keywords - Adaptive Reuse; Historical Building; Kota Tua; Toko Merah

\section{INTRODUCTION}

Architecture closely with the Building. Some types of buildings can be distinguished based on their age and make the building into a building because of its historical aspects both related to individuals, including areas or cities are quite thick. The buildings that become historical buildings need to be preserved, so that their architectural traces can still be studied and maintained. However, several historical buildings in Indonesia, especially in Jakarta, were abandoned and left unused without being used, this made the architectural function inaccessible to the wider community.

One of the right solutions to revive a historical area is to make a new function of the old functions in these buildings. This step is known as adaptive re-use which is then juxtaposed with the concept of conservation [1].

The Toko Merah is one of the historical buildings in Kota Tua (Old Town) of Jakarta which is very famous in Jakarta. The Toko Merah is a relic of the Dutch colonial building located in the west corner of Kali Besar, Kota Tua, Jakarta. It was built in 1730 . The characteristic, that is red color of this building makes this building called as Red Shop or in Indonesian language "Toko Merah.”

Architects and designers have the challenge to find innovative solutions to reuse of historic buildings and sites. According to development pressures in cities, more historical buildings are being reused, producing some excellent models of innovative designs that retain heritage value [2].
[3] stated that everything that is not used, whether it is a place, a region or a building that is old and damaged and not maintained, will create a view that disturbs anyone who sees it. This condition can occur because the place or building has no function and benefits. Ignorance and indifference are usually a big factor that makes a place or building abandoned. Actually, if everyone can be smarter and more accurate in looking at these conditions, there is a lot of potential in an abandoned and untreated old place or building. One step that can be done is to re-function a place or building that is no longer used as a place, building or something with a new function that can bring many benefits, and benefits from an economic, cultural and social perspective. This step is commonly known as Adaptive Reuse. Adaptive reuse or reuse in historical buildings is often juxtaposed with a conservation concept.

According to the law of Indonesian government, preservation of cultural heritage buildings that have important value for history is based on Article 4 of Law Number 11 of 2010 concerning Cultural Heritage, the scope of preservation of cultural heritage includes:

1. Protection, is an effort to prevent and overcome damage, destruction, or destruction by means of rescue, security, zoning, maintenance and restoration of cultural heritage.

2. Development, is an increase in the potential value, information, and promotion of cultural heritage and its utilization through research, revitalization, and adaptation in a sustainable manner and does not conflict with conservation goals.

3. Utilization, is the utilization of cultural heritage for the best interests of the people while maintaining its sustainability.

Referring to Regional Regulation Number 9 of 1999, the Old Town of Jakarta is a Cultural Heritage Area, so that the Old Town of Jakarta needs to be preserved through protection, development and utilization.

The protection, development and utilization efforts provided to Kota Tua Jakarta Area are realized through the issuance of the Republic of Indonesia's Government Regulation Number 50 of 2011 concerning the Master Plan for National Tourism Development in 2010-2015. It is stated that the Old Town of Sunda Kelapa and its surroundings are included in the National Tourism Development Zone. 


\section{CONCEPT OF ADAPTIVE REUSE}

Buildings are built for a specific function or use. However, the building often outlasts its original purpose. Adaptive reuse for historic buildings, structures, or sites is the most ideal approach to storing them that links the past with the present and future projects. Adaptive reuse is the conversion of buildings, sites, or districts from one use to another. When relic sites have been reused, new uses must support ongoing interpretation and understanding of temporary inheritance values and adjust new functions. Instead of trying to freeze historic buildings or sites, adaptive reuse can give new life to it. Adaptive reuse seeks alternatives between extreme demolition or turning the site into a museum. Adding a new layer without deleting the previous layer, the adaptive reuse project becomes part of a site's long history which is another stage, not the last result [4].

Historical buildings are expressions of large accumulations that reflect the cultural, social and economic structures of previous periods. These values have survived to this day. Protecting these values from extinction will result in the recovery of historic buildings for public use by updating them to the level of modern comfort and making necessary functional changes [5].

Buildings are usually built with specific uses in mind. Overtime, however, they often outlive their original purpose. Adaptive reuse is the act of modifying a building to accommodate uses that are different from those originally intended. These modifications are often accompanied by significant physical changes to the building [6].

[2] stated that adaptive reuse for historic building, structure or site is the most ideal approach to save it which interfaces the past to the present and projects into the future. Adaptive reuse is the conversion of a building, site or district from one use to another. When the heritage site has been reused, the new use should support the ongoing interpretation and understanding of the heritage value while as well as fitting new functions. Instead of seeking to freeze historical building or site, adaptive reuse can give new life to it.

[2] also stated that eight principles are proposed to be used to well adaptive reuse historical buildings:

1) Analyzing and understanding the significance of the structure as an essential and expressive part of the adaptation project.

2) Keeping a Building in Use by finding a new use which is suitable to the heritage value of the place.

3) Ensuring reversibility of alterations and avoiding the use of process or materials whose future removal would damage the original historic fabric.

4) Promoting minimum intervention based on respect for the existing building.

5) Respecting maximum retention of fabric and the least possible loss of the original fabric.

6) Conserving the relationship between the setting and preserve considerable views to and from the historical place.

7) Providing for the long-range management and viability of the historical structure.

8) Reveal and interpret the heritage significance.

\section{TOKO MERAH, KOTA TUA, JAKARTA}

The Toko Merah is one of the old buildings in the Kota Tua of Jakarta which is said to have a Chinese architectural style due to the red dominance of the building (although dark red). The Toko Merah building was founded in 1730 and then used as a residence for Gustaaf Willem Baron Van Imhoff during his tenure as Governor General of the VOC in 1743 - 1750

[7] stated that a further explanation of the meaning of the name of the Toko Merah (or Red Shop in English) is based on the color of the front wall of the building painted dark red directly on the surface of an unplastered brick. The dark red color also appears on the interior of the building which is mostly red with its carvings which are also red in color. In addition, in the land certificate No. 957, No. 958 dated July 13, 1920 stated that the parcels belonged to NV Bouwmaatschapij is called as "Toko Merah." The Toko Merah building consists of 2 buildings and had several times moved owners such as Jacob Mossel, the son of Governor General Mossel named Phillippine Theodore Mossel, Governor General Peter Albertus van der Parra, Renier de Klerk, Nicolaas Hartingh, Baron van Hohendorf, and others.

The history of this building functioned as a residence by Gustaaf Willem Baron van Imhoff in the Dutch era, then changed owners into a shop known as the Toko Merah. Long after that this building was used as the headquarters of N.V Jacobson van den Berg, one of the five major Dutch colonial companies. After that it was used as a health service building for the Japanese army, then occupied by a British-Indian joint army which only lasted approximately three years. Shortly afterwards, it became the N.V Jacobson van den Berg office, which was later nationalized as P. Yudha Bakti. Then at this time the Toko Merah was used as a rental building, wedding building or meeting [8].

Toko Merah has dark red color on all over its façade, as shown by Fig 1 . Façade of Toko Merah.



Figure 1. Façade of Toko Merah

\section{COMMUNITY PERCEPTION}

Descriptive research is research conducted to determine the value of an independent variable, either one variable or more (independent) without making comparisons, or connecting with other variables. Quantitative research, is research by obtaining data in the form of numbers or qualitative data that is assumed [9]. The data obtained from the sample population of the study were analyzed according to the statistical method used then interpreted. 
The sample in this study were people living around the Toko Merah and the people who visited the Toko Merah. Data is obtained by giving questions to the sample through a questionnaire. The sampling used was purposive sampling followed by snowball sampling. There were thirty-three respondents, with 5 respondents obtained by purposive sampling method, then the rest was obtained from the snowball sampling method.

Questions on the questionnaire about people's perceptions of the Red Store function are gradual, starting from demographic recognition to finally being able to draw conclusions about whether or not the current Toko Merah function is appropriate.

\section{A. Demographic Data}

Demographic data tried to find the ages and gender of respondent. Its is a must to know about the age of the respondents, because we need to know the age cohort of visitor that want to come to the old town of a city. And It was found that the respondents' ages varied from 16 years to 36 years, but the most respondents were at 21 years as much as $15.2 \%$, followed by 24 and 25 years, as shown by Figure 4 . Age of respondents. It is shown by Fig 2. Age variation of respondent.

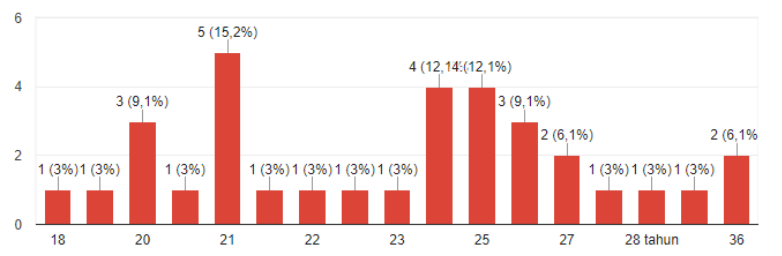

Figure 2. Age variation of respondent

A person's preference in choosing a location is influenced by one of them by gender. A location can be very crowded and favored by one gender, but there are also locations that are favored by all genders. It is shown by Fig 3 . The Percentage of Gender

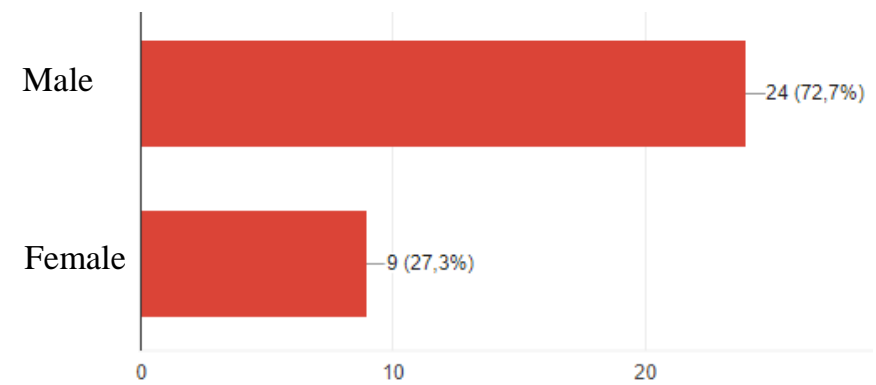

Figure 3. The Percentage of Gender

By knowing gender, there will be potential to conclude a result of data on their gender. Of all respondents who filled out the questionnaire, $72.7 \%$ were male or it is about twenty-four people, and $27.3 \%$ were female or it is about nine people.

\section{B. Community Awarness of Jakarta's Old Town}

The frequency of visits by respondents to Kota Tua Jakarta, and the results showed that 18 out of 33 respondents stated that the frequency was in number 5 from 1-5 points which meant that they often visited the Kota Tua of Jakarta.
Then followed by 8 of 33 people who stated that the frequency is in number 4, which means they often visit the Old City of Jakarta. Furthermore, the last known 7 out of 33 respondents claimed that they occasionally visit the Kota Tua of Jakarta for a month. It is shown by Fig 4. Frequency of respondents visiting Kota Tua, Jakarta

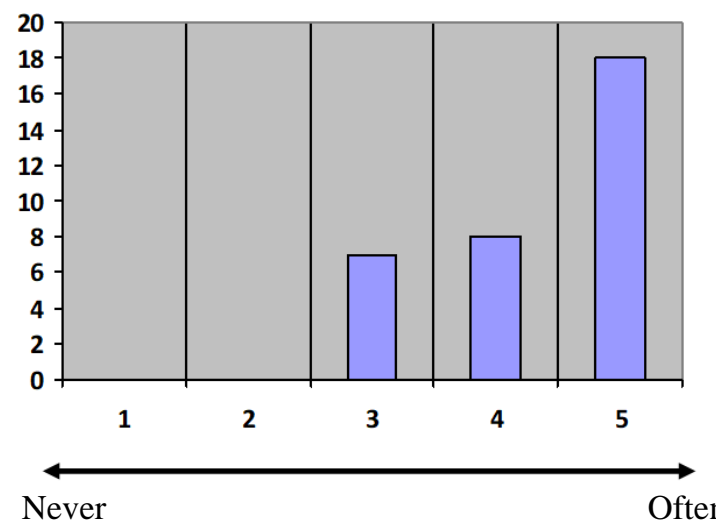

Figure 4. Frequency of respondents visiting Kota Tua, Jakarta

Next, it was find out about how big the suitability of the Toko Merah at this time according to the respondents. Answers from them were really varied. 14 respondents stated that the Toko Merah function is currently not appropriate by choosing the number 1 . They are gave a questionnaire with Likert scale, from the Likert scale (it is 1 to 5 ) or 1 for very inappropriate to 5 for very suitable. Then 14 others chose the number 2, 4 respondents chose number 3 , and 1 respondent chose number 4 . Thus it can be concluded that according to the community the function of the Toko Merah building is currently not appropriate.

Many argued that this discrepancy is caused because the Toko Merah function is not currently open to the public, the shape of the building is not suitable to become a wedding hall besides it does not have big parking lot, and the location is not suitable to make Toko Merah as wedding hall as well, it is make Kota Tua area more busy than ever when there is a wedding at that building. This Toko Merah suitability diagram is shown by Figure 5. Suitability of Toko Merah current function.

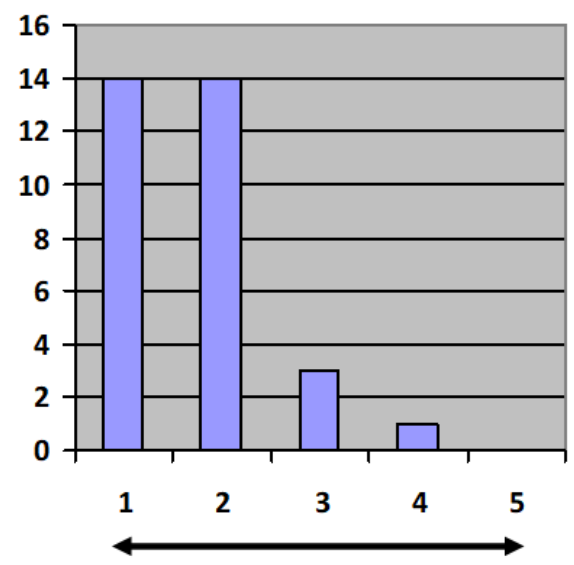

unsuitable

very suitable

Figure 5. Suitability of Toko Merah current function 
From figure 5, it can show that community said that the current Toko Merah function is not suitable, so they were gave questionnaire about the right function that suppose to replace the current Toko Merah fuction. From the questionnaire, there are 10 new functions that can replace the current Toko Merah function, they are hotels, food festivals, souvenir centers, meeting halls, restaurants, office rentals, museums, salons and spas, parking buildings, and showcase houses. After data collection, it is known that souvenir center, museum and restaurant are the three most functional choices, and itt is shown by Fig 6 . The possible function that can replace the current Toko Merah function


Figure 6. The possible function that can replace the current Toko Merah function

\section{CONCLUSSION}

Community that come to Kota Tua, Jakarta around 16 to 36 years old, and it found out that male visitors are dominate it. From 33 visitors that become respondents told that they often come to Kota Tua Jakarta, and they knew what Toko Merah is, they knew where Toko Merah is. Almost all of them said that Toko Merah current function is not a suitable function because the location of Toko Merah, because the shape of the building is not suitable as well, and because it is not open for public so they can not enjoy the building. Then they gave their opinion about the right function for Toko Merah, they said souvenir center of Kota Tua Jakarta is the best choice to replace the current function of Toko Merah.

\section{ACKNOWLEDGMENT}

Thanks to the LPPM of Universitas Muhammadiyah Jakarta for funding this research about Toko Merah suitability study through an internal grant of the "Penelitian Unggulan" of Universitas Muhammadiyah Jakarta with a Decree of the Rector of Universitas Muhammadiyah Jakarta Number 124 of 2018.

\section{REFERENCES}

[1] Sofiana, R., Purwantiasning, A. W., and Anisa, ADAPTIVE REUSE PADA BANGUNAN TUA BERSEJARAH Sebuah Kajian Konservasi Pada Kawasan Kota Lama Jakarta. Arsitektur UMJ Press, 2015.

[2] Ragheb, G., Ragheb, A. A., and Ragheb, R. A., Adaptive ReUse and Sustainable Development for Existing Historic Buildings - Case Study: Buildings of Racetrack Horses in Sporting Club, Alexandria, Egypt. International Journal of Current Engineering and Technology, Vol.7, No.4, pp. 1523 1530, August 2017.

[3] Saputra, $\mathrm{H}$ and Purwantiasning, A. W., Kajian Konsep Sebagai Alternatif Adaptive Reuse Aplikasi Konsep Konservasi. Jurnal Arsitektur Universitas Bandar Lampung, JA! No.4 Vol.1, pp. 45-52, 2013

[4] Clark, J., The Best Way to Conserve A Heritage Building, Structure or Site is to Use It, Adaptation Links The Past to The Present and Projects Into The Future. Heritage Council of Victoria, 2013.

[5] Ulusoy. M., Erdogan. E., Erdogan, H.A., and Orala, M. ReUsing of the Historical Buildings in the Context of Sustainability: An Architectural Design Studio Study on Old Girls Teacher Training School, International Archives of the Photogrammetry, Remote Sensing and Spatial Information Sciences, 2013.

[6] Conejos, S. H., Langston, C., Smith, J., Improving The Implementation of Adaptive Reuse Strategies for Historic Buildings. Institute of Sustainable Development and Architecture, 2011.

[7] Sejarah RI, Sejarah Toko Merah, http://sejarahri.com/sejarahtoko-merah/, accessed at $20^{\text {th }}$ July 2018, 22.23 WIB (UTC +7). 2016.

[8] Situs Budaya, Sejarah Toko Merah Jakarta, https://situsbudaya.id/sejarah-toko-merah-jakarta/, accessed at $27^{\text {th }}$ July 2018, 21.00 WIB (UTC +7). 2018.

[9] Sugiyono, Metode Penelitian Bisnis. Bandung: Alphabeta, 2003 